\title{
Conceptual Frameworks on How to Teach STEM Concepts in Bahasa Indonesia Subject as Integrated Learning in Grades 1-3 at Elementary School in the Curriculum 2013 to Contribute to Sustainability Education
}

\author{
Aceng Hasani ${ }^{1, *}$, Dase Erwin Juansah ${ }^{1}$, Indah Juwita Sari ${ }^{2}{ }^{\mathbb{C}}$ and R. Ahmad Zaky El Islami ${ }^{3}$ \\ 1 Department of Indonesian and Literature Education, Faculty of Teacher Training and Education, \\ Universitas Sultan Ageng Tirtayasa, Serang 42117, Indonesia; daseerwin77@untirta.ac.id \\ 2 Department of Biology Education, Faculty of Teacher Training and Education, \\ Universitas Sultan Ageng Tirtayasa, Serang 42117, Indonesia; indah.juwitasari@untirta.ac.id \\ 3 Department of Science Education, Faculty of Teacher Training and Education, \\ Universitas Sultan Ageng Tirtayasa, Serang 42117, Indonesia; zakyislami@untirta.ac.id \\ * Correspondence: aceng.hasani@untirta.ac.id
}

check for

updates

Citation: Hasani, A.; Juansah, D.E.; Sari, I.J.; El Islami, R.A.Z. Conceptual Frameworks on How to Teach STEM Concepts in Bahasa Indonesia Subject as Integrated Learning in Grades 1-3 at Elementary School in the Curriculum 2013 to Contribute to Sustainability Education.

Sustainability 2021, 13, 173.

https:/ / doi.org/10.3390/su13010173

Received: 7 December 2020

Accepted: 22 December 2020

Published: 27 December 2020

Publisher's Note: MDPI stays neutral with regard to jurisdictional clai$\mathrm{ms}$ in published maps and institutional affiliations.

Copyright: (C) 2020 by the authors. Licensee MDPI, Basel, Switzerland. This article is an open access article distributed under the terms and conditions of the Creative Commons Attribution (CC BY) license (https:// creativecommons.org/licenses/by/ $4.0 /)$.

\begin{abstract}
This study aimed to develop conceptual frameworks on how to teach STEM concepts in a Bahasa Indonesia subject as integrated learning. This study used a mixed-methods research design that consisted of a document analysis, a survey, and a systematic review. To address the aims of this study, we first determined the STEM concepts on basic competencies of a Bahasa Indonesia subject of Grades 1-3 at elementary school level in the curriculum 2013; the recommended teaching and learning strategies in learning STEM concepts integrated into a Bahasa Indonesia subject of Grades 1-3 at elementary school in the curriculum 2013; and the first proposed conceptual frameworks on how to teach STEM concepts in a Bahasa Indonesia subject as an integrated learning in Grades 1-3 at elementary school level in the curriculum 2013 based on systematic review. The results showed that the conceptual frameworks on how to teach science concepts in a Bahasa Indonesia subject as integrated learning in Grades 1-3 at elementary school level in the curriculum 2013 consisted of Bahasa Indonesia as the main goal and science concepts as an approach to address goals, and recommends it be taught using reading. The conceptual framework on how to teach technology concepts in a Bahasa Indonesia subject as an integrated learning in Grades 1-3 at elementary school level in the curriculum 2013 consisted of Bahasa Indonesia as the main goal and technology concepts as an approach to address goals, and recommends that it be taught using reading. These findings will be useful to Indonesian teachers and teachers in other countries that have integrated science or STEM concepts in the language subject in their curricula as integrated learning or will use integrated learning in their future curricula to contribute to sustainability education.
\end{abstract}

Keywords: STEM concepts; Bahasa Indonesia subject; teaching and learning; conceptual framework; integrated learning

\section{Introduction}

To address sustainability in the education field, some scholars have conducted innovative research to integrate some arts, humanities, and natural science topics into the education field such as indigenous knowledge and Western science integrated into science education [1]. In this era, the integration of some disciplines has started to focus on the teaching and learning process such as in integrated Science, Technology, Engineering, and Mathematics (STEM) education. STEM education has become a big issue in the science education field worldwide, and [2] since 2019, it has started being well-known in the Indonesian community through workshops, conferences, and research collaboration such as Model based Integrated Inquiry in STEM (MII-STEM) at http:/ / miistem.org. Indonesia has 
had a new curriculum since 2013, which uses thematic learning such as science concepts learned in a Bahasa Indonesia subject as integrated learning in an elementary school in Grades 1-3 [3-6]. The rule of language is the logical device, and we can make explicit meaning of the sentences by using examples [7]. Schumacer [8] state that language teachers can teach science concepts by using an integrated curriculum.

In the Curriculum 2013, the learning of science in Grades 1-3 is integrated into the subjects of Bahasa Indonesia and mathematics by integrating the basic competence of the science subject into the basic competence of Bahasa Indonesia and mathematics subjects [3-6]. At the same time, science begins to be taught as a subject from Grade 4 to Grade 6 in elementary schools [3-6]. However, this does not make students in Grades 1-3 unable to recognize the concept of science from Grade 1 because students can learn the concepts of science through the subjects that have been mentioned, one of them being Bahasa Indonesia.

The Bahasa Indonesia subject is one of the subjects that has a basis as a language subject, and this has its uniqueness when it comes to learning the concepts of science through a Bahasa Indonesia subject. Therefore, research needs to be done that can integrate the concepts of science with the Bahasa Indonesian subject. In the curriculum 2013, all learning processes at the elementary school level are taught using themes to integrate all subjects except mathematics and physical and health education from Grades 4 to 6 [5,6]. As science is taught as a subject from Grades 4 to 6 in elementary schools, the Grades 4-6 are clear in how to use science as a subject to integrate with other subjects using themes in the learning process. However, it is not easy to use Bahasa Indonesia integrated science as one subject in Grades 1-3 to integrate with other subjects using themes in the learning process. Therefore, more research is needed on how to teach science concepts in a Bahasa Indonesia subject as integrated learning in Grades 1-3.

Currently, science education has been developing toward STEM education, and it can be seen in the development of STEM education studies originating from science education as conducted by $[9,10]$, who adapted the science literacy framework at PISA $2006[11,12]$ became STEM literacy $[9,10]$. The authors in [13] state that true STEM education should increase the students' understanding of how things work and improve their use of technologies. Even though the curriculum has not explicitly integrated STEM education in its curriculum in Indonesia, we can actually find STEM concepts. Therefore, it is necessary to identify STEM concepts in the curriculum 2013, especially in Bahasa Indonesia subjects in Grades 1-3, because in those grades, science concepts are taught in Bahasa Indonesia subject. Then, research is needed on how to teach STEM concepts in a Bahasa Indonesia subject as integrated learning.

Previous research on how to teach integration in a STEM discipline and language discipline has been carried out by [14], which integrated foreign languages and information technology. Morska et al [14] found that an integrated approach was an effective approach to teaching future programmers professional, communicative competence in a foreign language as mastering a foreign language is a complex process, which included mastering linguistic and extralinguistic knowledge, skills, and experience. However, previous research has not specifically integrated the concepts of foreign languages and information technology to be taught at the elementary school level. Ahlskog-Björkman \& E.; Björklund [15] and E.; Björklund \& Ahlskog-Björkman [16] studied integrated learning, which focused on integration and relations of the two knowledge areas in mathematics and art, and found a tendency to express learning goals where mathematics was in the foreground and art as an approach. However, these previous studies did not integrate STEM discipline and language. Nambiar \& bt Anawar [17] integrated local knowledge into English language learning. However, they did not integrate STEM discipline and language. Zakaria \& Aziz [18] integrated digital storytelling on language. However, this study was conducted in secondary school, not elementary school. Chen [19] investigated young children's science and aesthetic learning through an aesthetic science thematic curriculum. However, this previous study was conducted in preschool, not elementary 
school, and not integrated science and language. Sulisworo [20] integrated the Internet of Things (IoT) in thematic learning and created a learning design that integrated IoT in thematic learning in elementary schools on issues about climate change. However, the same as [14], although conducted at the 5th grade elementary school level, it was not specific to low-grade elementary school learning or Grades 1-3. Based on previous studies, the aim of this study was to develop conceptual frameworks on how to teach STEM concepts in a Bahasa Indonesia subject as integrated learning. However, before that, it is necessary to first examine what STEM concepts are contained in the Grades 1-3 curriculum at the elementary school in the curriculum 2013 and how the experts recommend teaching it, so this framework will be useful for Indonesian teachers and teachers in other countries that have integrated the science or STEM concepts in the language subject in their curricula as integrated learning or will use integrated learning in their future curricula to contribute to sustainability education.

\section{Methods}

This study used a mixed-methods research design [21] because we investigated the qualitative and quantitative data and combined it. This study used a document analysis to determine the STEM concepts in the curriculum, a survey to get the recommendations from the experts on how to teach STEM concepts in Bahasa Indonesia subject, and a systematic review to find the proposed frameworks on how to teach STEM concepts in a Bahasa Indonesia subject. This study analyzed Indonesia's curriculum 2013 document to explore and determine the STEM concepts on basic competencies of Bahasa Indonesiasubject in Grades 1-3 at the elementary school level [21]. In this study, the document of basic competence of the Bahasa Indonesia subject in the curriculum 2013 was used from the basic competence in year 2013 by [3] to determine the STEM concepts in the curriculum and use the results to develop the framework on how to teach STEM concepts in a Bahasa Indonesia subject as integrated learning. In the additional method, this study used a survey using an instrument developed using the basic competence in year 2013 by [3], nature of science by [22-24], nature of technology by [22,25,26], nature of engineering by [27], and nature of mathematics by [22] (in Appendix A) to obtain the learning and teaching strategies that science and Indonesian language education experts recommend [21]. The survey instrument (in Appendix A) was validated on content and language by five experts including a science lecturer, chemistry lecturer, biology lecturer, physics lecturer, and Indonesian language lecturer. These were the Assistant Professors and Associate Professors from the Department of Indonesian Language and Literature Education, Department of Biology Education, Department of Chemistry Education, Department of Physics Education, and Department of Science Education. The respondents in this survey consisted of four experts in the Indonesian language education fields from the Department of Indonesian Language and Literature Education and four experts in the science education field from the Department of Physics Education, Department of Biology Education, and Department of Chemistry Education to obtain the recommendations on teaching and learning strategies in teaching STEM concepts in a Bahasa Indonesia subject. We invited the experts in science education and Indonesian language education fields to become voluntary respondents. We limited the experts to at least an Assistant Professor in the science education and Indonesian language education fields to get the recommendations from two different fields because this study is an interdisciplinary study between the science education and Indonesian language fields.

Additionally, this study used a systematic review to develop a proposed conceptual framework on how to teach STEM concepts in Bahasa Indonesia subject as integrated learning by using the Web of Science database including selected seven articles. The steps in this systematic review were adapted from [28], which consists of five steps: Reviewing the question; finding the evidence; appraising qualitative research; sampling; and synthesis of the qualitative research. The first step is to review the question, where the question in this systematic review was: "What are the frameworks on how to teach 
STEM concepts in the Bahasa Indonesia subject as integrated learning?". The second step is finding the evidence. We used the Web of Science database as one of the best databases that consists of the best selected journals by logging into the Web of Science database and using the topic "integrated learning", and we obtained 43,938 sources at http:/ / apps.webofknowledge.com.portal.lib.ku.ac.th/Search.do?product=WOS\&SID= F6m6ClcZn8P7BKcVHMX\&search_mode=GeneralSearch\&prID=42acf415-6652-4874-9c5c5f878a418405 (Note: this link only can be accessed by logging into the Web of Science database through an account at Kasetsart University). The third step is appraising the qualitative research. In this step, we were limited to only five years from 2016-2020, thematic learning, education educational research and education scientific disciplines categories, article type to get the quality of sources, and we obtained 119 articles at http:/ / apps. webofknowledge.com.portal.lib.ku.ac.th/Search.do?product=WOS\&SID=F6m6ClcZn8P7BK cVHMX\&search_mode=GeneralSearch\&prID $=4 \mathrm{fbcc} 3 \mathrm{cf}-0310-4 \mathrm{c} 0 \mathrm{c}-\mathrm{ae} 2 \mathrm{e}-6 \mathrm{f16fb0a63ec}$ (Note: this link only can be accessed by logging into the Web of Science database through an account at Kasetsart University). The fourth step is sampling, where we screened 119 articles. To get the appropriate sources for this study, with a focus on primary school, we were limited to those articles that related to one level before primary school (pre-primary school) level, primary school level, and one closer level after primary school (post-primary school) level, and obtained seven articles. The fifth step was the synthesis of the qualitative research, and we developed the first proposed conceptual framework on how to teach STEM concepts in a Bahasa Indonesia subject as integrated learning by using seven articles.

Finally, in developing a conceptual framework on how to teach STEM concepts in a Bahasa Indonesia subject as integrated learning in Grades 1-3 at the elementary school level, we used triangulation using the document analysis results, survey results, and the systematic review results.

\section{Results and Discussion}

\section{A. The STEM Concepts on Basic Competencies of Bahasa Indonesia Subject of Grades 1-3 at Elementary School Level in the Curriculum 2013.}

There are 51 basic competencies in Bahasa Indonesia subject for Grades 1-3 in the curriculum 2013, which consist of 17 basic competencies in Grades 1, 2, and 3. There are 30 basic competencies in the Bahasa Indonesia subject related to STEM concepts in Grades 1-3 (60\%), which consists of eight basic competencies in Grade $1(47 \%)$, seven basic competencies in Grade 2 (41\%), and 15 basic competencies in Grade $3(88 \%)$. The basic competencies related to STEM concepts can be seen in Tables 1-3.

Table 1. Basic competencies relating to STEM concepts in Grade 1.

\begin{tabular}{|c|c|c|}
\hline No. & Basic Competencies [3] & STEM Concepts \\
\hline 1 & $\begin{array}{l}\text { 2.1. Have concern and curiosity for the existence of forms and properties of objects through Bahasa Indonesia } \\
\text { and/or local language. }\end{array}$ & Science \\
\hline 2 & 2.2. Have confidence in the existence of the body through Bahasa Indonesia and/or local language. & Science \\
\hline 3 & $\begin{array}{l}\text { 2.3. Have discipline and responsibility for caring for the body to be healthy and fit through Bahasa Indonesia } \\
\text { and/or local language. }\end{array}$ & Science \\
\hline 4 & $\begin{array}{l}\text { 2.5. Have polite and honest behavior in terms of activities and playing in the environment through Bahasa } \\
\text { Indonesia and/or local language. }\end{array}$ & Science \\
\hline 5 & $\begin{array}{l}\text { 3.1. Know descriptive texts about limbs and senses, form and nature of objects, and events day and night with } \\
\text { the help of a teacher or friend in spoken and written Bahasa Indonesia that can be filled with local language } \\
\text { vocabulary to help them understand. }\end{array}$ & Science \\
\hline 6 & $\begin{array}{l}\text { 3.2. Know text instructions/directives about body care and maintenance of health and fitness with the help of a } \\
\text { teacher or friend in spoken and written Bahasa Indonesia that can be filled with local language vocabulary to } \\
\text { help them understand. }\end{array}$ & Science \\
\hline 7 & $\begin{array}{l}\text { 4.1. Observing and imitating descriptive texts about limbs and senses, forms and properties of objects as well as } \\
\text { day and night events independently in oral and written Bahasa Indonesia that can be filled with local language } \\
\text { vocabulary to help the presentation. }\end{array}$ & Science \\
\hline 8 & $\begin{array}{l}\text { 4.2. Practice guided texts/instructions on caring for the body and body health and fitness independently in } \\
\text { spoken and written Bahasa Indonesia that can be filled with local language vocabulary to help with the } \\
\text { presentation. }\end{array}$ & Science \\
\hline
\end{tabular}


Table 2. Basic competencies relating to STEM concepts in Grade 2.

\begin{tabular}{|c|c|c|}
\hline No. & Basic Competencies [3] & STEM Concepts \\
\hline 1 & $\begin{array}{l}\text { 2.1. Have concern and curiosity for the surrounding nature, animals, and plants through Bahasa } \\
\text { Indonesia and/or local language. }\end{array}$ & Science \\
\hline 2 & $\begin{array}{l}\text { 2.2. Have polite and honest behavior in terms of activities and playing in the environment through } \\
\text { Bahasa Indonesia and/or local language. }\end{array}$ & Science \\
\hline 3 & $\begin{array}{l}\text { 3.1. Know the text of a simple report about the surrounding nature, animals, and plants and their } \\
\text { numbers with the help of a teacher or friend in spoken and written Bahasa Indonesia that can be } \\
\text { filled with local language vocabulary to help them understand. }\end{array}$ & Science \\
\hline 4 & $\begin{array}{l}\text { 3.2. Know simple narrative text activities and play in the environment with the help of teachers or } \\
\text { friends in spoken and written Bahasa Indonesia that can be filled with local language vocabulary to } \\
\text { help them understand. }\end{array}$ & Science \\
\hline 5 & $\begin{array}{l}\text { 3.4. Know the lyrics of poem texts about the universe and their appearance with the help of a } \\
\text { teacher or friend in spoken and written Bahasa Indonesia that can be filled with local language } \\
\text { vocabulary to help them understand. }\end{array}$ & Science \\
\hline 6 & $\begin{array}{l}\text { 4.1. Observe and try to present a simple report text about the surrounding nature, animals, and } \\
\text { plants, and their numbers independently in oral and written Bahasa Indonesia that can be filled } \\
\text { with local language vocabulary to help the presentation. }\end{array}$ & Science \\
\hline 7 & $\begin{array}{l}\text { 4.2. Demonstrate simple narrative text stories about activities and play in the environment } \\
\text { independently in spoken and written Bahasa Indonesia that can be filled with local language } \\
\text { vocabulary to help the presentation. }\end{array}$ & Science \\
\hline
\end{tabular}

Table 3. Basic competencies relating to STEM concepts in Grade 3.

\begin{tabular}{|c|c|c|}
\hline No. & Basic Competencies [3] & STEM Concepts \\
\hline 1 & $\begin{array}{l}\text { 2.1. Have concern and a sense of responsibility toward living things, energy and climate change, } \\
\text { and the Earth and the universe through Bahasa Indonesia and/or local language. }\end{array}$ & Science \\
\hline 2 & $\begin{array}{l}\text { 2.2. Have discipline and responsibility for healthy living and caring for animals and plants through } \\
\text { Bahasa Indonesia and/or local language. }\end{array}$ & Science \\
\hline 3 & $\begin{array}{l}\text { 2.3. Have polite and honest behavior toward the development of production, communication, and } \\
\text { transportation technology and social problems in the region through Bahasa Indonesia and/or } \\
\text { local language. }\end{array}$ & Technology \\
\hline 4 & $\begin{array}{l}\text { 2.4. Have confidence and care for natural conditions and the social environment through Bahasa } \\
\text { Indonesia and/or local language. }\end{array}$ & Science \\
\hline 5 & 2.5. Have concern for animal and plant life through Bahasa Indonesia and/or local language. & Science \\
\hline 6 & $\begin{array}{l}\text { 3.1. Extract information from informative report texts on observations about changes in the form of } \\
\text { objects, energy sources, changes in energy, alternative energy, climate and weather changes, the } \\
\text { shape of the Earth and its changes as well as the universe with the help of teachers and friends in } \\
\text { spoken and written Bahasa Indonesia with local language vocabulary to help them understand. }\end{array}$ & Science \\
\hline 7 & $\begin{array}{l}\text { 3.2. Describe direction texts/instructions on animal and plant care and animal life cycle and plant } \\
\text { breeding with the help of teachers or friends in spoken and written Bahasa Indonesia that can be }\end{array}$ & Science \\
\hline$\gamma$ & filled with local language vocabulary to help them understand. & science \\
\hline 8 & $\begin{array}{l}\text { 3.3. Presenting the contents of the text of the personal response letter regarding the development of } \\
\text { production, communication, and transportation technology as well as problems and social } \\
\text { environment in the area with the help of teachers and friends in spoken and written Bahasa } \\
\text { Indonesia that can be filled with local language vocabulary to help them understand. }\end{array}$ & Technology \\
\hline 9 & $\begin{array}{l}\text { 3.4. Extract information from fairytale texts about natural conditions with the help of teachers or } \\
\text { friends in spoken and written Bahasa Indonesia that can be filled with local language vocabulary to } \\
\text { help them understand. }\end{array}$ & Science \\
\hline 10 & $\begin{array}{l}\text { 3.5. Extract information from local game/dolanan texts about animal and plant life with the help of } \\
\text { a teacher or friend in spoken and written Bahasa Indonesia that can be filled with local language } \\
\text { vocabulary to help them understand. }\end{array}$ & Science \\
\hline 11 & $\begin{array}{l}\text { 3.6. Observing and processing the contents of the informative report text of observations about } \\
\text { changes in the form of objects, energy sources, energy changes, alternative energy, climate and } \\
\text { weather changes, Earth's appearance and changes, and the universe independently in oral and } \\
\text { written Bahasa Indonesia that can be filled with vocabulary local languages to help the } \\
\text { presentation. }\end{array}$ & Science \\
\hline
\end{tabular}


Table 3. Cont.

\begin{tabular}{|c|c|c|}
\hline No. & Basic Competencies [3] & STEM Concepts \\
\hline 12 & $\begin{array}{l}\text { 4.2. Explain and practice directed texts/instructions on animal and plant care and the life cycle of } \\
\text { animals and plant breeding independently in spoken and written Bahasa Indonesia that can be } \\
\text { filled with local language vocabulary to assist in the presentation. }\end{array}$ & Science \\
\hline 13 & $\begin{array}{l}\text { 4.3. Process and present the text of a personal response letter regarding the development of } \\
\text { production, communication, and transportation technology as well as problems and social } \\
\text { environment in the area independently in spoken and written Bahasa Indonesia that can be filled } \\
\text { with local language vocabulary to assist in the presentation. }\end{array}$ & Technology \\
\hline 14 & $\begin{array}{l}\text { 4.4. Delivering fairytale texts about natural conditions in the form of independent role play in } \\
\text { spoken and written Bahasa Indonesia that can be filled with local language vocabulary to help with } \\
\text { the presentation. }\end{array}$ & Science \\
\hline 15 & $\begin{array}{l}\text { 4.5. Demonstrate local game/dolanan texts about animal and plant life independently in oral and } \\
\text { written Bahasa Indonesia that can be filled with local language vocabulary to assist in the } \\
\text { presentation. }\end{array}$ & Science \\
\hline
\end{tabular}

Based on Tables 1-3 are the obtained data that the STEM concepts integrated into the Bahasa Indonesian subject are the concepts of science and technology, and do not include the concepts of engineering and mathematics, even though researchers plan to investigate all four STEM concepts including science, technology, engineering, and mathematics. As for the proportion in each grade; for Grade 1, there were $100 \%$ basic competencies related to the concept of science, for Grade 2, there were $100 \%$ basic competencies related to the concept of science, while for Grade 3, there were $20 \%$ basic competencies related to the concept of technology and $80 \%$ of basic competencies were related to the concept of science. American Association for the Advancement of Science (AAAS) [22] describes that the nature of science includes the scientific world view, scientific inquiry, and the scientific enterprise. Lederman et al [23] describe the six characteristics of science and scientific knowledge, include that students should be aware of the crucial distinction between observation and inference; closely related to the distinction between observations and inferences is the distinction between scientific laws and theories, even though scientific knowledge is, at least partially, based on and/or derived from observations of the natural world (i.e., empirical), it nevertheless involves human imagination and creativity, scientific knowledge is subjective or theory-laden, science as a human enterprise is practiced in the context of a larger culture and its practitioners (scientists) are the product of that culture. Additionally, [23] stated that the scientific knowledge is never absolute or certain. Michel \& Neumann [24] states that in general, NOS is viewed as an important topic to be taught in school science, and together with knowledge of scientific concepts, to contribute to scientific literacy. Based on [22-24], we interpreted the data in Tables 1-3 to determine science. AAAS [22] stated that technology does not just provide tools for science, but can also provide motivation and direction for theory and research. Feenberg [25] stated that technology is the medium of daily life. Cajas [26] states that technology can be seen as an artifact, knowledge, and social practice. Based on [22,25,26], we interpreted the data in Tables 1-3 to determine technology. Science and technology are part of STEM education. As [29] states, STEM refers to Science, Technology, Engineering, and Mathematics, a term first described by Judith Ramaley in 2001 as the Assistant Director of Education and Human Resources Directorate at the National Science Foundation (NSF). [30] stated that integrated STEM education can integrate two or more of the STEM subject areas, which is similar to [31], and [32] stated that integrated STEM education could integrate two or some or all of the four disciplines of science, technology, engineering, and mathematics. However, [10] stated that the meaning of STEM education is not clear and distinct. There is a reference to four disciplines, but sometimes the meaning and emphasis only include one discipline. In this study, we concluded that the Bahasa Indonesia subject integrated two disciplines of STEM education, which were science and technology, separately, which can be integrated into the Bahasa Indonesia subject, as stated by [10] that the term STEM may be separately four disciplines. Additionally, science can be integrated into the Bahasa Indonesia subject 
as [17] used the framework to integrate the language as the main goal and science as an approach to address the goals. Additionally, technology can be integrated into a Bahasa Indonesia subject as [18] used the framework to integrate the language as the main goal and technology as an approach to address the goals.

B. The Recommended Teaching and Learning Strategies in Learning STEM Concepts Integrated into Bahasa Indonesia Subject of Grades 1-3 at Elementary School in the Curriculum 2013.

Based on the results of a survey of four Indonesian language education experts and four science education experts, the data contained in Table 4, Figures 1 and 2 can be obtained.

Table 4. Recommended teaching and learning strategies in learning science and technology concepts integrated into a Bahasa Indonesia subject for Grades 1-3 at elementary school in the curriculum 2013 based on STEM concepts and grades.

\begin{tabular}{ccccccc}
\hline No. & STEM Concepts and Grade & \multicolumn{5}{c}{ Experts Recommendations (\%) } \\
\hline 1 & Science in Grade 1 (\%) & 30.00 & 18.18 & 6.36 & 22.73 & 22.73 \\
2 & Science in Grade 2 (\%) & 36.46 & 26.04 & 5.21 & 11.46 & 20.83 \\
3 & Science in Grade 3 (\%) & 37.20 & 26.22 & 3.66 & 4.27 & 28.66 \\
4 & Technology in Grade 3 (\%) & 34.15 & 31.71 & 2.44 & 2.44 & 29.27 \\
\hline
\end{tabular}

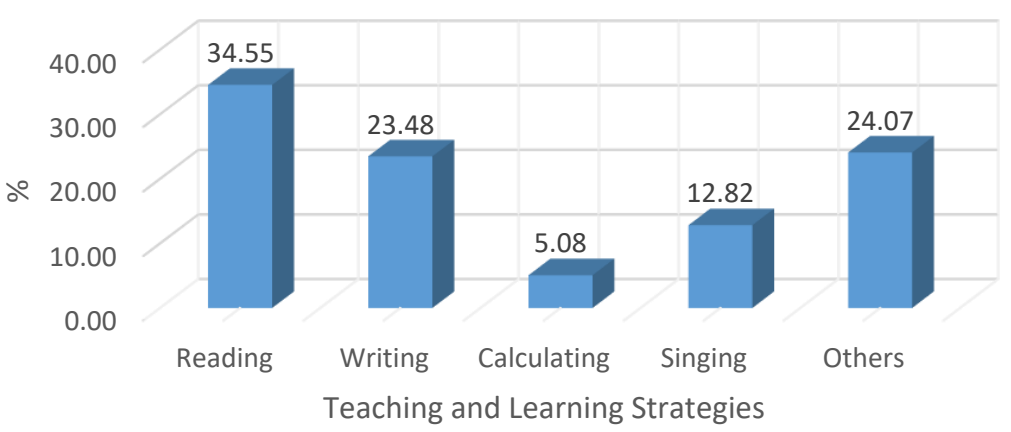

Figure 1. The recommended teaching and learning strategies in learning science concepts integrated into the Bahasa Indonesia subject of Grades 1-3 at elementary school in the curriculum 2013 based on STEM concepts and grades based on STEM concepts.

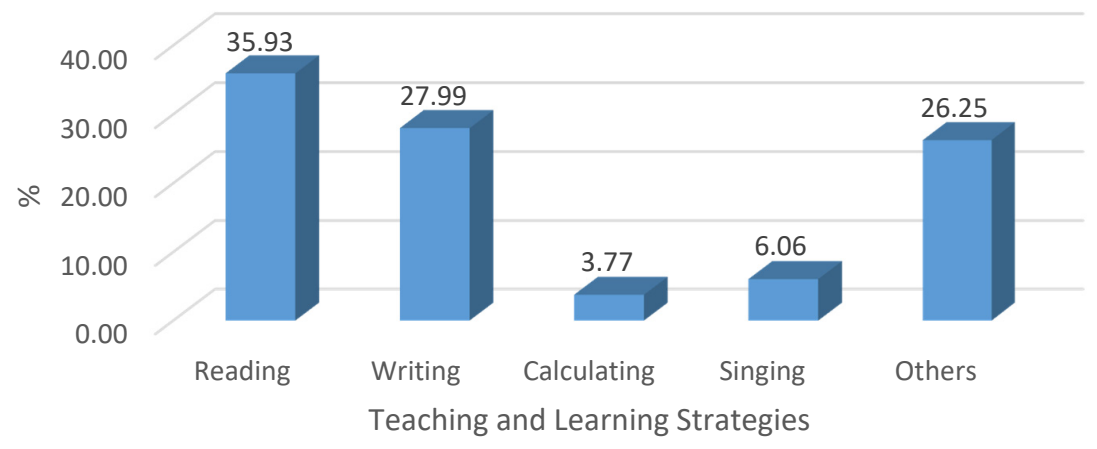

Figure 2. The recommended teaching and learning strategies in learning technology concepts integrated into Bahasa Indonesia subject of Grades 1-3 at elementary school in the curriculum 2013 based on STEM concepts and grades based on STEM concepts.

Based on Table 4 and Figures 1 and 2, we can see that the most recommended teaching and learning strategies for Grades 1-3 for science concepts integrated into a Bahasa Indonesia subject are reading. Additionally, the most recommended teaching and learning strategies in Grade 3 for technology concepts that integrated into a Bahasa Indonesia subject are also reading. This finding is similar to [33], who found that by using written 
communication such as reading the written text and graphics, students used visual activity, which allows students to understand the environmental management concepts that include science and technology concepts easier. Furthermore, the respondents of experts in the Indonesian language education and science education fields have more experience based on psychological aspects, content aspects, and educational aspects, so the recommendations will have strengths and can be references to teach STEM concepts in Bahasa Indonesia subjects for Grades 1-3 at the elementary school level.

C. The First Proposed Conceptual Frameworks on How to Teach STEM Concepts in Bahasa Indonesia Subject as Integrated Learning in Grades 1-3 at Elementary School Level in the Curriculum 2013 Based on Systematic Review. Table 5.

Based on a systematic review of selected seven articles, we obtained the results in

Table 5. The framework of seven previous studies about integrated learning of two disciplines.

\begin{tabular}{|c|c|c|c|c|c|c|}
\hline No. & Author, Year & Title & $\begin{array}{c}\text { Framework-Based } \\
\text { Theory }\end{array}$ & & $\begin{array}{l}\text { tioning One Discipline to } \\
\text { lother Discipline in the } \\
\text { Integrated Learning }\end{array}$ & Conclusion \\
\hline 1 & $\begin{array}{c}\text { Ahlskog-Björkman \& } \\
\text { Björklund, } 2016\end{array}$ & $\begin{array}{c}\text { Patterns of } \\
\text { awareness-preschool } \\
\text { teachers' integration of art } \\
\text { and mathematics }\end{array}$ & Sociocultural theory & $>$ & $\begin{array}{l}\text { Mathematics as the } \\
\text { primary goal } \\
\text { The meaning of art in } \\
\text { thematic work was } \\
\text { expressed as follows: } \\
\text { starting with art; framing } \\
\text { with art, and parallel } \\
\text { entrance to the theme }\end{array}$ & $\begin{array}{l}\text { Mathematics as the } \\
\text { main goal and art as } \\
\text { an approach to } \\
\text { address the goals }\end{array}$ \\
\hline 2 & Lin \& Lo, 2017 & $\begin{array}{l}\text { Trans/languaging and the } \\
\text { triadic dialogue in content } \\
\text { and language integrated } \\
\text { learning (CLIL) classrooms }\end{array}$ & $\begin{array}{l}\text { Social semiotics } \\
\text { theory and } \\
\text { sociocultural theory }\end{array}$ & $>$ & $\begin{array}{l}\text { Practice using academic } \\
\text { language, either in speech } \\
\text { or writing, to ensure that } \\
\text { they had grasped the } \\
\text { academic literacy skills } \\
\text { Science as content }\end{array}$ & $\begin{array}{c}\text { The balance between } \\
\text { science and language } \\
\text { as the main goals and } \\
\text { approaches }\end{array}$ \\
\hline 3 & $\begin{array}{c}\text { Björklund \& } \\
\text { Ahlskog-Björkman, } \\
2017\end{array}$ & $\begin{array}{l}\text { Approaches to teaching in } \\
\text { thematic work: early } \\
\text { childhood teachers' } \\
\text { integration of mathematics } \\
\text { and art }\end{array}$ & Sociocultural Theory & $\begin{array}{l}> \\
>\end{array}$ & $\begin{array}{l}\text { Mathematics as the main } \\
\text { goal } \\
\text { The meaning of art in } \\
\text { thematic work was } \\
\text { expressed as follows: } \\
\text { starting with art, framing } \\
\text { with art, and parallel } \\
\text { entrance to the theme }\end{array}$ & $\begin{array}{l}\text { Mathematics as the } \\
\text { main goal and } \\
\text { language as an } \\
\text { approach to address } \\
\text { the goals }\end{array}$ \\
\hline 4 & $\begin{array}{l}\text { Nambiar \& Anawar, } \\
2017\end{array}$ & $\begin{array}{c}\text { Integrating Local } \\
\text { Knowledge into Language } \\
\text { Learning: A Study on the } \\
\text { Your Language My Culture } \\
\text { (YLMC) Project }\end{array}$ & Sociocultural Theory & $>$ & $\begin{array}{l}\text { Language as the main } \\
\text { goal } \\
\text { Local or international } \\
\text { culture as content in the } \\
\text { module }\end{array}$ & $\begin{array}{l}\text { Language as the } \\
\text { main goal and } \\
\text { science as an } \\
\text { approach to address } \\
\text { the goals }\end{array}$ \\
\hline 5 & Sulisworo et al., 2019 & $\begin{array}{l}\text { The Collaborative } \\
\text { Environment Using The } \\
\text { Internet Of Things In The } \\
\text { Thematic Based Learning } \\
\text { At The Primary School In } \\
\text { Indonesia }\end{array}$ & $\begin{array}{l}\text { Constructivism } \\
\text { Theory }\end{array}$ & $\begin{array}{l}> \\
>\end{array}$ & $\begin{array}{l}\text { Internet of Things (IoT) } \\
\text { as media } \\
\text { Science as the main goal }\end{array}$ & $\begin{array}{l}\text { Science as the main } \\
\text { goal and technology } \\
\text { as an approach to } \\
\text { address the goals }\end{array}$ \\
\hline 6 & $\begin{array}{l}\text { Zakaria and Aziz, } \\
2019\end{array}$ & $\begin{array}{l}\text { The Impact of Digital } \\
\text { Storytelling on ESL } \\
\text { Narrative Writing Skill }\end{array}$ & $\begin{array}{l}\text { Constructivism } \\
\text { Theory }\end{array}$ & $\begin{array}{l}> \\
>\end{array}$ & $\begin{array}{l}\text { Digital Storytelling as } \\
\text { media } \\
\text { Students' narrative } \\
\text { writing essay in terms of } \\
\text { vocabulary, grammar, } \\
\text { content, and overall } \\
\text { performance as goals }\end{array}$ & $\begin{array}{l}\text { Language as the } \\
\text { main goal and } \\
\text { technology as an } \\
\text { approach to address } \\
\text { the goals }\end{array}$ \\
\hline
\end{tabular}


Table 5. Cont.

\begin{tabular}{|c|c|c|c|c|c|}
\hline No. & Author, Year & Title & $\begin{array}{c}\text { Framework-Based } \\
\text { Theory }\end{array}$ & $\begin{array}{l}\text { Positioning One Discipline to } \\
\text { Another Discipline in the } \\
\text { Integrated Learning }\end{array}$ & Conclusion \\
\hline 7 & Chen, 2020 & $\begin{array}{l}\text { An investigation of young } \\
\text { children's science and } \\
\text { aesthetic learning through a } \\
\text { science aesthetic thematic } \\
\text { curriculum: A } \\
\text { mixed-methods study }\end{array}$ & $\begin{array}{l}\text { Behaviorist Theory } \\
\text { and Dewey's Theory }\end{array}$ & 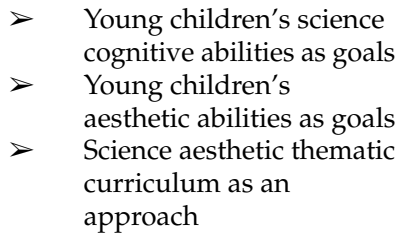 & $\begin{array}{l}\text { The balance between } \\
\text { science and art as } \\
\text { goals and using } \\
\text { science aesthetic } \\
\text { thematic curriculum } \\
\text { to address the goals }\end{array}$ \\
\hline
\end{tabular}

Based on Table 5, we can conclude that there are two main types of framework to teach integrated learning. First, one discipline is used as the main goal and another as an approach to address goals [15-18]; the second is balancing between two disciplines as goals and/or approaches to address goals [19,20,34]. The first type was divided into three frameworks consisting of mathematics as the main goal and art as an approach to address the goals [15,16]; language as the main goal and science as an approach to address the goals [17]; and science as the main goal and technology as an approach to address the goals [20]. The second type was divided into two frameworks consisting of a balance between science and language as the main goals and approaches [3], and a balance between science and art as goals and using a science aesthetic thematic curriculum to address the goals [19].

The first proposed conceptual frameworks on how to teach STEM concepts in a Bahasa Indonesia subject as integrated learning in Grades 1-3 at elementary school level in the curriculum 2013 can use two types that are Bahasa Indonesia as the main goal and STEM concepts as an approach to address goals as in previous studies by [15-18].

The first type of proposed conceptual framework in this study is one of the integration curriculum levels, as [8] divided. This type is complementary in that the teachers involve science or technology in the Bahasa Indonesia subject as integrated learning to address some topics [8].

The second type of the proposed conceptual framework in this study is one of the levels of integration curriculum, as [8] divided. This type is webbed in balancing between Bahasa Indonesian and STEM concepts as goals and/or approaches to address goals. Teachers from all disciplines work together in collaboration to teach STEM concepts in the Bahasa Indonesia subject to address the goals from all disciplines including science and language [8].

D. A Conceptual Framework on How to Teach STEM Concepts in Bahasa Indonesia Subject as Integrated Learning in Grades 1-3 at the Elementary School Level in the Curriculum 2013.

A conceptual framework on how to teach STEM concepts in the Bahasa Indonesiasubject as integrated learning in Grades 1-3 at elementary school level was investigated using triangulation based on the document analysis results, the systematic review results, and the survey results. Based on the document analysis results, we can observe that the STEM concepts in Grades 1 and 2 are science concepts, and that the Grade 3 concepts are science and technology. Based on the survey results of eight experts in science education and Indonesian language education experts, we obtained recommendations that the most recommended teaching and learning strategies in Grades 1-3 for science concepts integrated into the Bahasa Indonesia subject were reading. Additionally, the most recommended teaching and learning strategies in Grade 3 for technology concepts integrated into Bahasa Indonesia subject were also reading. Based on the systematic review results, the first proposed conceptual frameworks on how to teach STEM concepts in the Bahasa Indonesia subject as integrated learning in Grades 1-3 at elementary school level in the curriculum 2013 can use two types: (1) Bahasa Indonesia as the main goal and STEM concepts as 
an approach to address goals, and (2) balancing between Bahasa Indonesia and STEM concepts as goals and/or approaches to address goals.

Based on these three types of results, we used triangulation to develop a conceptual framework on how to teach STEM concepts in a Bahasa Indonesia subject as integrated learning in Grades 1-3 at the elementary school level in the curriculum 2013. Ministry of Education and Culture [4] stated that in the curriculum 2013 in Indonesia, the science subject in the elementary school begins from Grade 4 . However, the science concepts are learned in the Bahasa Indonesia subject in Grades 1-3. Schumacher [8] stated that this type was complementary as the teachers involved science or technology in the Bahasa Indonesia subject as integrated learning to address some topics. Based on the policy from [4] and the theory from [8], we can use the framework on how to teach STEM concepts in the Bahasa Indonesia subject as integrated learning in Grades 1-3 at the elementary school level in the curriculum 2013 where we positioned Bahasa Indonesia as the main goal and STEM concepts as an approach to address the goals. However, the science concept in the curriculum 2013 is available in Grades 1-3, and the technology concept is only available in Grade 3. Both science and technology are learned separately in science and technology terms, and not in integrated STEM. This study proposed two frameworks: (1) a conceptual framework consisting of how to teach science concepts in the Bahasa Indonesia subject as integrated learning in Grades 1-3 at elementary school level in the curriculum 2013, and a conceptual framework on how to teach technology concepts in the Bahasa Indonesia subject as integrated learning in Grades 1-3 at elementary school level in the curriculum 2013.

A conceptual framework on how to teach science concepts in the Bahasa Indonesia subject as integrated learning in Grades 1-3 at elementary school level in the curriculum 2013 consists of Bahasa Indonesia as the main goal and science concepts as an approach to address goals, and the recommendation is that it is taught through reading. Furthermore, a conceptual framework on how to teach technology concepts in the Bahasa Indonesia subject as integrated learning in Grades 1-3 at elementary school level in the curriculum 2013 consists of Bahasa Indonesia as the main goal and technology concepts as an approach to address goals, again which is recommended to be taught through reading

\section{Education. \\ E. The Importance and Implications of These New Frameworks to Sustainability}

The importance of these new conceptual frameworks on how to teach science and technology concepts in the Bahasa Indonesia subject as integrated learning in Grades 1-3 at the elementary school level in the curriculum 2013 is giving teachers an understanding of how to teach science and technology in the Bahasa Indonesia subject so that teachers will not confuse teaching science and technology in the Bahasa Indonesia subject. The teacher will understand that the science and technology concepts in the Bahasa Indonesia subject are approaches to address the goal of the Bahasa Indonesia subject. An example of this is addressing the goal of basic competence 3.1 on knowing descriptive texts about limbs and senses, form, and nature of objects, and events day and night with the help of a teacher or friend in spoken and written Bahasa Indonesia that can be filled with local language vocabulary to help them to understand [3]. To address the goal of speaking and writing in Bahasa Indonesia, teachers can use the texts about limbs and senses, form, and nature of objects, and events day and night as approach in the learning process. Actually, through this framework, students can not only speak and write in Bahasa Indonesia, but can also understand the science concepts. However, teachers must understand that the understanding of science is not the main goal, only the additional understanding, so that teachers can focus on how to increase the students' ability to speak and write in Bahasa Indonesia. Additionally, the teaching and learning processes recommended by experts was to use a reading strategy by both the teacher and student in order for students to know before speaking and writing in Bahasa Indonesia about limbs and senses, the form, and nature of objects, and events day and night.

These new conceptual frameworks will significantly impact the quality and sustainability of education in Indonesia and other countries worldwide. We can see that the impact 
of the learning process is not only about understanding the use of the mother language, but also understanding the science and technology concepts as additional understanding. If many countries use this framework from the first grade, it will help students to understand their mother language and science and technology at the same time. Furthermore, students will understand that addressing some knowledge, skills, or attitudes is not a must from one subject, but can be created from many subjects in an integrated manner. Additionally, students will be more interested in learning language, science, and technology because learning will be more simply in one subject than separately in language as a subject, science as a subject, and technology as a subject, which needs more time to learn in the classroom. Finally, reading, as a teaching and learning strategy recommended by experts to be used in the learning process of language subject in this study, Bahasa Indonesia, which integrated science and technology concepts, will help teachers and students to improve the quality of learning.

\section{Conclusions}

The STEM concepts that are integrated into the Bahasa Indonesia subject in Grades 1-2 are science concepts, and the concepts in Grade 3 are science and technology. Most of the recommended teaching and learning strategies in Grades 1-3 for science concepts integrated into the Bahasa Indonesia subject involve reading. Additionally, the most recommended teaching and learning strategies in Grade 3 for technology concepts integrated into the Bahasa Indonesia subject were also reading. One of the conceptual frameworks on how to teach science concepts in Bahasa Indonesia subject as integrated learning in Grades 1-3 at elementary school level in the curriculum 2013 consists of Bahasa Indonesia as the main goal and science concepts as an approach to address goals, and were recommended to be taught through reading. Another conceptual framework on how to teach technology concepts in the Bahasa Indonesia subject as integrated learning in Grades 1-3 at elementary school level in the curriculum 2013 consists of Bahasa Indonesian as the main goal and technology concepts as an approach to address goals, and it also recommended to be taught through reading. Future study needs to explore the teaching and learning strategies recommended by experts in each basic competence of the Bahasa Indonesia subject. These findings will be useful to Indonesian teachers and teachers in other countries that have integrated science or STEM concepts in the language subject in their curricula as integrated learning to contribute to sustainability education.

Author Contributions: Conceptualization, A.H., D.E.J., I.J.S. and R.A.Z.E.I.; Methodology, A.H., D.E.J., I.J.S. and R.A.Z.E.I.; Software, A.H., D.E.J., I.J.S. and R.A.Z.E.I.; Validation, A.H., D.E.J., I.J.S. and R.A.Z.E.I.; Formal analysis, A.H., D.E.J., I.J.S. and R.A.Z.E.I.; Investigation A.H., D.E.J., I.J.S. and R.A.Z.E.I.; Resources, A.H., D.E.J., I.J.S. and R.A.Z.E.I.; Data curation, A.H., D.E.J., I.J.S. and R.A.Z.E.I.; Writing—original draft preparation, A.H., D.E.J., I.J.S. and R.A.Z.E.I.; Writingreview and editing, A.H., D.E.J., I.J.S. and R.A.Z.E.I.; Visualization A.H., D.E.J., I.J.S. and R.A.Z.E.I.; Supervision A.H., D.E.J., I.J.S. and R.A.Z.E.I.; Project administration A.H., D.E.J., I.J.S. and R.A.Z.E.I.; Funding acquisition, A.H. and D.E.J. All authors have read and agreed to the published version of the manuscript.

Funding: This research received no external funding.

Institutional Review Board Statement: Not applicable.

Informed Consent Statement: Not applicable.

Data Availability Statement: The data presented in this study are available in this article.

Acknowledgments: The authors thank experts; Aditya Rakhmawan, Erwin Salpa Riansi, Asep Saefullah, Dwi Ratnasari, Eka Yusmaita, who validated the instrument that we used in this research. We also thank all Indonesian language education and science education experts as respondents in this research, and Kasetsart University, which facilitated the researchers in using an account to access the Web of Science database.

Conflicts of Interest: The authors declare no conflict of interest. 


\section{Appendix A}

\section{Instrument (in English Translation)}

Fill in the recommended teaching and learning strategy section and then adjust it to the basic competencies available by using the following options.

* You can choose more than one choice
A. Reading
B. Writing
C. Calculating
D. Singing
E. Other

Table A1. Basic competencies relating to STEM concepts in Grade 1.

\begin{tabular}{|c|c|c|c|}
\hline No. & Basic Competencies & STEM Concepts & $\begin{array}{c}\text { Recommended } \\
\text { Teaching and Learning } \\
\text { Strategies }\end{array}$ \\
\hline 1 & $\begin{array}{l}\text { 2.1. Have concern and curiosity for the existence of forms and } \\
\text { properties of objects through Bahasa Indonesia and/or local language. }\end{array}$ & Science & \\
\hline 2 & $\begin{array}{l}\text { 2.2. Have confidence in the existence of the body through Bahasa } \\
\text { Indonesia and/or local language. }\end{array}$ & Science & \\
\hline 3 & $\begin{array}{l}\text { 2.3. Have discipline and responsibility for caring for the body to be } \\
\text { healthy and fit through Bahasa Indonesia and/or local language. }\end{array}$ & Science & \\
\hline 4 & $\begin{array}{l}\text { 2.5. Have polite and honest behavior in terms of activities and playing } \\
\text { in the environment through Bahasa Indonesia and/or local language. }\end{array}$ & Science & \\
\hline 5 & $\begin{array}{l}\text { 3.1. Know descriptive texts about limbs and senses, form, and nature of } \\
\text { objects, and events day and night with the help of a teacher or friend in } \\
\text { spoken and written Bahasa Indonesia that can be filled with local } \\
\text { language vocabulary to help them understand. }\end{array}$ & Science & \\
\hline 6 & $\begin{array}{l}\text { 3.2. Know text instructions/directives about body care and } \\
\text { maintenance of health and fitness with the help of a teacher or friend in } \\
\text { spoken and written Bahasa Indonesia that can be filled with local } \\
\text { language vocabulary to help them understand. }\end{array}$ & Science & \\
\hline 7 & $\begin{array}{l}\text { 4.1. Observing and imitating descriptive texts about limbs and senses, } \\
\text { forms, and properties of objects as well as day and night events } \\
\text { independently in oral and written Bahasa Indonesia that can be filled } \\
\text { with local language vocabulary to help with the presentation. }\end{array}$ & Science & \\
\hline 8 & $\begin{array}{l}\text { 4.2. Practice guided texts/instructions on caring for the body and body } \\
\text { health and fitness independently in spoken and written Bahasa } \\
\text { Indonesia that can be filled with local language vocabulary to help } \\
\text { with the presentation. }\end{array}$ & Science & \\
\hline No. & Basic Competencies & STEM Concepts & $\begin{array}{c}\text { Recommended } \\
\text { Teaching and Learning } \\
\text { Strategies }\end{array}$ \\
\hline 1 & $\begin{array}{l}\text { 2.1. Have concern and curiosity for the surrounding nature, animals, } \\
\text { and plants through Bahasa Indonesia and/or local language. }\end{array}$ & Science & \\
\hline 2 & $\begin{array}{l}\text { 2.2. Have polite and honest behavior in terms of activities and playing } \\
\text { in the environment through Bahasa Indonesia and/or local language. }\end{array}$ & Science & \\
\hline 3 & $\begin{array}{l}\text { 3.1. Know the text of a simple report about the surrounding nature, } \\
\text { animals, and plants and their numbers with the help of a teacher or } \\
\text { friend in spoken and written Bahasa Indonesia that can be filled with } \\
\text { local language vocabulary to help them understand. }\end{array}$ & Science & \\
\hline
\end{tabular}


Table A2. Cont.

\begin{tabular}{|c|c|c|c|}
\hline No. & Basic Competencies & STEM Concepts & $\begin{array}{l}\text { Recommended } \\
\text { Teaching and Learning } \\
\text { Strategies }\end{array}$ \\
\hline 4 & $\begin{array}{l}\text { 3.2. Know simple narrative text activities and play in the environment } \\
\text { with the help of teachers or friends in spoken and written Bahasa } \\
\text { Indonesia that can be filled with local language vocabulary to help } \\
\text { them understand. }\end{array}$ & Science & \\
\hline 5 & $\begin{array}{l}\text { 3.4. Know the lyrics of poem texts about the universe and their } \\
\text { appearance with the help of a teacher or friend in spoken and written } \\
\text { Bahasa Indonesia that can be filled with local language vocabulary to } \\
\text { help them understand. }\end{array}$ & Science & \\
\hline 6 & $\begin{array}{l}\text { 4.1. Observe and try to present a simple report text about the } \\
\text { surrounding nature, animals, and plants, and their numbers } \\
\text { independently in oral and written Bahasa Indonesia that can be filled } \\
\text { with local language vocabulary to help with the presentation. }\end{array}$ & Science & \\
\hline 7 & $\begin{array}{c}\text { 4.2. Demonstrate simple narrative text stories about activities and play } \\
\text { in the environment independently in spoken and written Bahasa } \\
\text { Indonesia that can be filled with local language vocabulary to help the } \\
\text { presentation. }\end{array}$ & Science & \\
\hline
\end{tabular}

Table A3. Basic competencies relating to STEM concepts in Grade 3.

\begin{tabular}{|c|c|c|c|}
\hline No. & Basic Competencies & STEM Concepts & $\begin{array}{l}\text { Recommended } \\
\text { Teaching and Learning } \\
\text { Strategies }\end{array}$ \\
\hline 1 & $\begin{array}{l}\text { 2.1. Have concern and a sense of responsibility towards living things, } \\
\text { energy and climate change, and the earth and the universe through } \\
\text { Bahasa Indonesia and/or local language. }\end{array}$ & Science & \\
\hline 2 & $\begin{array}{l}\text { 2.2. Have discipline and responsibility for healthy living and caring for } \\
\text { animals and plants through Bahasa Indonesia and/or local language. }\end{array}$ & Science & \\
\hline 3 & $\begin{array}{l}\text { 2.3. Have polite and honest behavior towards the development of } \\
\text { production, communication, and transportation technology and social } \\
\text { problems in the region through Bahasa Indonesia and/or local } \\
\text { language. }\end{array}$ & Technology & \\
\hline 4 & $\begin{array}{l}\text { 2.4. Have confidence and care for natural conditions and the social } \\
\text { environment through Bahasa Indonesia and/or local language. }\end{array}$ & Science & \\
\hline 5 & $\begin{array}{l}\text { 2.5. Have concern for animal and plant life through Bahasa Indonesia } \\
\text { and/or local language. }\end{array}$ & Science & \\
\hline 6 & $\begin{array}{l}\text { 3.1. Extract information from informative report texts on observations } \\
\text { about changes in the form of objects, energy sources, changes in energy, } \\
\text { alternative energy, climate and weather changes, the shape of the earth } \\
\text { and its changes, as well as the universe with the help of teachers and } \\
\text { friends in spoken and written Bahasa Indonesia with local language } \\
\text { vocabulary to help them understand. }\end{array}$ & Science & \\
\hline 7 & $\begin{array}{l}\text { 3.2. Describe direction texts/instructions on animal and plant care and } \\
\text { animal life cycle and plant breeding with the help of teachers or friends } \\
\text { in spoken and written Bahasa Indonesia that can be filled with local } \\
\text { language vocabulary to help them understand. }\end{array}$ & Science & \\
\hline 8 & $\begin{array}{l}\text { 3.3. Presenting the contents of the text of the personal response letter } \\
\text { regarding the development of production, communication, and } \\
\text { transportation technology as well as problems and social environment } \\
\text { in the area with the help of teachers and friends in spoken and written } \\
\text { Bahasa Indonesia that can be filled with local language vocabulary to } \\
\text { help them understand. }\end{array}$ & Technology & \\
\hline
\end{tabular}


Table A3. Cont.

\begin{tabular}{lcc}
\hline No. Basic Competencies & STEM Concepts & $\begin{array}{c}\text { Recommended } \\
\text { Teaching and Learning } \\
\text { Strategies }\end{array}$ \\
\hline
\end{tabular}

3.4. Extract information from fairytale texts about natural conditions

9 with the help of teachers or friends in spoken and written Bahasa

Indonesia that can be filled with local language vocabulary to help Science

them understand.

3.5. Extract information from local game/dolanan texts about animal and plant life with the help of a teacher or friend in spoken and written Bahasa Indonesia that can be filled with local language vocabulary to help them understand.

3.6. Observing and processing the contents of the informative report text of observations about changes in the form of objects, energy sources, energy changes, alternative energy, climate and weather changes, Earth's appearance and changes, and the universe

independently in oral and written Bahasa Indonesia that can be filled with vocabulary local languages to help the presentation.

4.2. Explain and practice directed texts/instructions on animal and

plant care and the life cycle of animals and plant breeding
independently in spoken and written Bahasa Indonesia that can be filled with local language vocabulary to assist in the presentation.

Science

4.3. Process and present the text of a personal response letter regarding the development of production, communication, and transportation technology as well as problems and social environment in the area independently in spoken and written Bahasa Indonesia that can be filled with local language vocabulary to assist in the presentation.

Science

4. Delivering fairytale texts about natural conditions in the form of

14 independent role play in spoken and written Bahasa Indonesia that can be filled with local language vocabulary to help with the presentation.

Technology

Science

4.5. Demonstrate local game/dolanan texts about animal and plant life

15 independently in oral and written Bahasa Indonesia that can be filled with local language vocabulary to assist in the presentation.

* Source: Ministry of Education and Culture. (2013a). Kompetensi Dasar Sekolah Dasar (SD)/Madrasah Ibtidaiyah (MI). Ministry of Education and Culture: Jakarta.

Thank you very much for your participation!

\section{References}

1. Zidny, R.; Eilks, I. Integrating Perspectives from Indigenous Knowledge and Western Science in Secondary and Higher Chemistry Learning to Contribute to Sustainability Education. Sustanable Chem. Pharm. 2020, 16, 100229. [CrossRef]

2. Parmin, P.; Saregar, A.; Deta, U.A.; El Islami, R.A.Z. Indonesian Science Teachers' Views on Attitude, Knowledge, and Application of STEM. J. Educ. Gift. Young Sci. 2020, 8, 17-31. [CrossRef]

3. Ministry of Education and Culture. Kompetensi Dasar Sekolah Dasar (SD)/Madrasah Ibtidaiyah (MI); Ministry of Education and Culture: Jakarta, Indonesia, 2013.

4. Ministry of Education and Culture. Peraturan Menteri Pendidikan dan Kebudayaan Nomor 67 Tahun 2013 tentang Kerangka Dasar dan Struktur Kurikulum Sekolah Dasar/Madrasah Ibtidaiyah; Ministry of Education and Culture: Jakarta, Indonesia, 2013.

5. Ministry of Education and Culture. Silabus Mata Pelajaran Sekolah Dasar/Madrasah Ibtidaiyah (SD/MI) Tematik Terpadu; Ministry of Education and Culture: Jakarta, Indonesia, 2016.

6. Ministry of Education and Culture. Model Silabus Mata Pelajaran Sekolah Dasar/Madrasah Ibtidaiyah (SD/MI) Tematik Terpadu; Ministry of Education and Culture: Jakarta, Indonesia, 2017.

7. Hutten, E.H. Natural and Scientific Language. Philosophy 1954, 29, 27-43. [CrossRef]

8. Schumacher, D.H. Five Levels of Curriculum Integration Defined, Refined, and Described. Res. Middle Level Educ. 1995, 18, 73-94. [CrossRef]

9. Bybee, R.W. Advancing STEM education: A 2020 vision. Technol. Eng. Teach. 2010, 70, 30-35.

10. Bybee, R.W. The Case for STEM Education: Challenges and Opportunities; National Science Teachers Association, NSTA Press: Arlington, Virginia, 2013. 
11. OECD. Executive Summary PISA 2006: Science Competencies for Tomorrow's World; OECD Publishing: Paris, France, 2007.

12. Bybee, R.; McCrae, B.; Laurie, R. PISA 2006: An assessment of scientific literacy. J. Res. Sci. Teach. 2009, 46, 865-883. [CrossRef]

13. Bybee, R.W. What is STEM education? Science 2010, 329, 996. [CrossRef]

14. Morska, L.I.; Skibska, J.; Sulym, V.T.; Masztalir, V.V. Didactic Potential of The Integrated Approach to Teaching Future Programmers Professional Communicative Competence In a Foreign Language. Inf. Technol. Learn. Tools 2018, 64, 1-12. [CrossRef]

15. Ahlskog-Björkman, E.; Björklund, C. Patterns of awareness-preschool teachers' integration of art and mathematics. Int. J. Educ. Through Art 2016, 12, 167-180. [CrossRef]

16. Björklund, C.; Ahlskog-Björkman, E. Approaches to teaching in thematic work: Early childhood teachers' integration of mathematics and art. Int. J. Early Years Educ. 2017, 25, 98-111. [CrossRef]

17. Nambiar, R.M.K.; bt Anawar, N.A. Integrating Local Knowledge into Language Learning: A Study on the Your Language My Culture (YLMC) Project. Arab World Engl. J. (AWEJ) 2017, 8, 167-182. [CrossRef]

18. Zakaria, M.A.; Aziz, A.A. The Impact of Digital Storytelling on ESL Narrative Writing Skill. Arab World Engl. J. (AWEJ) 2019, 5, 319-322. [CrossRef]

19. Chen, Y. An investigation of young children's science and aesthetic learning through a science aesthetic thematic curriculum: A mixed-methods study. Australas. J. Early Child. 2020, 45, 127-141. [CrossRef]

20. Sulisworo, D.; Suwondo, N.; Erviana, V.Y.; Fitrianawati, M. The Collaborative Environment Using The Internet of Things in The Thematic Based Learning at the Primary School in Indonesia. Inf. Technol. Learn. Tools 2019, 72, 55-66. [CrossRef]

21. Creswell, J. Qualitative Inquiry and Research Design: Choosing Among Five Approaches; Sage Publiucations: Southend Oaks, CA, USA, 2013.

22. American Association for the Advancement of Science. Science for all Americans; Oxford University Press: New York, NY, USA, 1990.

23. Lederman, N.G.; Lederman, J.S.; Antink, A. Nature of science and scientific inquiry as contexts for the learning of science and achievement of scientific literacy. Int. J. Educ. Math. Sci. Technol. 2013, 1, 138-147.

24. Michel, H.; Neumann, I. Nature of Science and Content Learning. Sci. Educ. 2016, 25, 951-975. [CrossRef]

25. Feenberg, A. Questioning Technology; Routledge: London, UK, 1999.

26. Cajas, F. Introducing Technology in Science Education: The Case of Guatemala. Bull. Sci. Technol. Soc. 1988, 18, 194-203. [CrossRef]

27. Yata, T.; Ohtani, T.; Isobe, M. Conceptual framework of STEM based on Japanese subject principles. Int. J. Stem Educ. 2020, 7, 1-10. [CrossRef]

28. Dixon-Woods, M.; Bonas, S.; Booth, A.; Jones, D.R.; Miller, T.; Shaw RL Young, B. How can systematic reviews incorporate qualitative research? A critical perspective. Qual. Res. 2006, 6, 27-44. [CrossRef]

29. Zollman, A. Learning for STEM Literacy: STEM Literacy for Learning. Sch. Sci. Math. 2012, 112, 12-19. [CrossRef]

30. Sanders, M. Integrative STEM education: Primer. Technol. Teach. 2009, 68, 20-27.

31. Moore, T.; Stohlmann, M.; Wang, H.; Tank, K.; Glancy, A.; Roehrig, G. Implementation and Integration of Engineering in K-12 STEM Education; Engineering in Pre-College Settings: Synthesizing Research, Policy, and Practices; Purzer, S., Strobel, J., Cardella, M., Eds.; Purdue University Press: West Lafayette, IN, USA, 2014; pp. 35-60.

32. Kelley, T.R.; Knowles, J.G. A Conceptual Framework for Integrated STEM Education. Int. J. Stem Educ. 2016, 3, 11. [CrossRef]

33. Sari, I.J.; Murni, D.; Sjaifuddin, S. Peningkatan Kecakapan Komunikasi Siswa Menggunakan Pembelajaran Bilingual Preview Review dengan Setting Jigsaw pada Konsep Pengelolaan Lingkungan. J. Penelit. Dan Pembelajaran IPA 2016, 2, 121-130. [CrossRef]

34. Lin, A.M.Y.; Lo, Y.Y. Trans/languaging and the triadic dialogue in content and language integrated learning (CLIL) classrooms. Lang. Educ. 2017, 31, 26-45. [CrossRef] 